\title{
Combining terrestrial laser scanning and root exposure to estimate erosion rates
}

\author{
J. A. Ballesteros-Cánovas • C. Corona • M. Stoffel • \\ A. Lucia-Vela $\cdot$ J. M. Bodoque
}

Received: 30 October 2014 / Accepted: 11 May 2015 / Published online: 23 May 2015

(C) Springer International Publishing Switzerland 2015

\begin{abstract}
Aims This paper aims to analyze the reliability of exposed roots oriented perpendicular to the slope to quantify sheet erosion rates based on accurate reconstruction of topography using terrestrial laser scanner (TLS).

Methods The study was performed in an experimental sandy badland located in Central Spain. Sampling procedures were conducted in three different homogenous hydrological response units (HRU). We derived eroded soil thickness from by obtaining accurate microtopographic data using TLS. In addition, dendrogeomorphic procedures, based on anatomical changes in root rings, were
\end{abstract}

Responsible Editor: Alain Pierret.

J. A. Ballesteros-Cánovas $(\bowtie) \cdot$ M. Stoffel

Dendrolab.ch, Institute of Geological Sciences, University of Berne, 3012 Berne, Switzerland

e-mail: juan.ballesteros@dendrolab.ch

J. A. Ballesteros-Cánovas • M. Stoffel

Climatic Change and Climate Impacts, Institute for

Environmental Sciences, University of Geneva,

1227 Carouge, Switzerland

C. Corona

CNRS Geolab Clermont-Ferrand, Clermont-Ferrand, France

M. Stoffel

Department of Earth and Environmental Sciences, University

of Geneva, 1205 Geneva, Switzerland

A. Lucia-Vela

Free University of Bolzano, Bolzano, Italy

J. M. Bodoque

University of Castilla-La Mancha, Toledo, Spain used to determine the first year of exposure of 46 Pinus pinaster roots.

Results Results indicate that medium-term ( \pm 30 year) erosion rates obtained from roots growing perpendicular to the slope were significantly different from those obtained from exposed roots growing parallel to the slope (p-value $<0.05$ ). However, at short term (up to 5 years), result agree with those obtained from erosion pin monitoring at the study site, which confirms the potential of reconstructions based on perpendicular roots.

Conclusion The utility of exposed perpendicular roots coupled with accurate eroded soil estimation has been proved. It allows the extension of the applicability of dendrogeomorphic approaches, particularly for ungauged badlands where instrumental data is scarce or completely missing.

Keywords Sheet erosion · Exposed roots · Terrestrial laser scanner · Badlands · Dendrogeomorphology · Tree ring $\cdot$ Erosion rate

\section{Introduction}

Sheet erosion processes are the key driver of soil degradation in arid or semi-arid areas (Verheijen et al. 2009; Nadal-Romero et al. 2011), although intense rates have also been observed in environments with severe seasonal weather and intense geomorphic activity (de Aguiar et al. 2010). Erosion processes can be categorized as highly irregular (Walling and Webb 1986), and are controlled by 
environmental factors and human activities (Hooke 2000; Poesen et al. 2003; Montgomery 2007) which often lead to serious impacts on the hydrology and carbon cycle (Quinton et al. 2010; Spalevic et al. 2012). The understanding of erosion processes and their drivers is therefore a global issue with large economic and ecological implications (Pimentel 2006; Morgan 2009). However, limited knowledge still exists on how erosion processes evolve over time and on what their impact are on changes in environmental conditions (Poesen et al. 2003; Poesen 2011; Nadal-Romero et al. 2015).

The development of methodologies capable of quantifying erosion rates retrospectively and at different spatio-temporal scales still is a major scientific challenge (Poesen et al. 2003; Poesen 2011). In this regard, bioindicators - such as exposed roots - can be an alternative method to determine erosion rates at shortto medium term timescales (Stoffel et al. 2013), especially in vegetated, and ungauged catchments. This approach allows estimation of erosion rates with (sub-) annual precision over decadal timescales and with reasonable spatial resolution (Stoffel et al. 2013); it is based on the fact that roots modify cellular anatomy once they are exposed, thus permitting detection and dating of the first year of exposure (Carrara and Carroll 1979; Gärtner et al. 2001; McAuliffe et al. 2006; Rubiales et al. 2008; Corona et al. 2011). However, and despite the advantage presented by root-based erosion rate quantification in terms of spatial replicability and the possibility to assess erosion rates retrospectively (Stoffel et al. 2013; Ballesteros-Cánovas et al. 2013), the method has not been applied as frequently as other approaches such as direct measurement using pins (i.e., Godfrey et al. 2008) or photogrammetry (i.e., Rieke-Zapp and Nearing 2005; Martínez-Casanovas et al. 2009; Giménez et al. 2009; Gómez-Gutiérrez et al. 2014).

From a methodological perspective, major (recent) advances in root-based erosion rate estimations are related (i) the high reliability and accuracy of exposure signals and ways to detect based on anatomical changes in root wood (Rubiales et al. 2008; Corona et al. 2011) and (ii) the impedance of soil to determine the depth of the eroded soil layer more accurately (Gärtner 2007; Corona et al. 2011). So far, existing studies have been based exclusively on exposed roots orientated in parallel position (PAR) to the slope, which may reduce significantly the number of samples available for analysis, even more so on slopes with strong erosion where tree cover tends to be scarce (Bodoque et al. 2005, 2011;
McAuliffe et al. 2006; Sun et al. 2014). Perpendicular roots (PER), by contrast, have been systematically disregarded in the past as they were thought to induce a bias to reconstruction as a result of sedimentation upslope of the root and scour erosion in the downslope direction (Gärtner et al. 2001; Bodoque et al. 2005, 2011; Corona et al. 2011; Lopez-Sáez et al. 2011; Sun et al. 2014).

On the other hand, Terrestrial Laser Scanner (TLS) allows of the acquisition of highly-accurate topographic data around exposed roots, which enable the analysis of micro-topographic conditions and the accurate reconstruction of the eroded soil. Ballesteros-Cánovas et al. (2013) and Stoffel et al. (2013) underline the important role that micro-topography around roots has on reconstructed erosion rates and therefore called for a careful consideration of uncertainties related to topography next to exposed roots when it comes to the quantification of eroded soil layers. More recently, Bodoque et al. (2015) have, in addition, estimated that uncertainties related to micro-topography may represent up to $50 \%$ of the eroded soil layer in silica badlands.

In this study, we examine the hypothesis that information from PER in combination with microtopographic analysis can be used to properly reconstruct and quantify erosion rates. Our objective therefore is to provide a new methodology to estimate erosion rates based on exposed PER roots using information contained in root-ring series and high-resolution topographic information (TLS). Our analysis is performed in an experimental badland site vegetated by Pinus pinaster Ait., and characterized by the existence of a high density of exposed roots with different spatial configurations. Moreover, the study benefits from results of previous research conducted at the study site, such that data obtained here can be compared with short-term erosion rate records derived from direct, local measurements, as well as with a medium-term erosion rate reconstruction derived from exposed root growing parallel (PAR) to the slope.

\section{Material and methods}

Description of the study site

The study site for this experimental approach is a badland called Barranca de los Pinos and located in the 
north of the Spanish Central System, in the Segovia province $\left(41^{\circ} 9^{\prime} 30^{\prime \prime} \mathrm{N} ; 3^{\circ} 48^{\prime} 30^{\prime \prime} \mathrm{W}\right)$ at an elevation of $1065 \mathrm{~m}$ asl (Fig. 1). Geologically, this area is characterized by Upper Cretaceous, horizontally-bedded outcrops (dolostone and limestone) underlain by fluvial (gravelly clayey and silica sand) sediments (Lucia et al. 2011). These deposits form a set of mesas and cuestas with carbonatic caprocks whose slopes are usually covered by a thick carbonatic colluvium. In these environments, soils can be defined as rendzic leptosols and colluvial regosols. Where colluvial formations have been removed, the area is characterized by outcrops of highly erodible silica sand layers (Lucia et al. 2011).

Climatic conditions at the site are defined as temperate with dry and warm summers (Csb types, Köppen classification; CNIG 2004), moderate average annual precipitation $(680 \mathrm{~mm})$ and moderate temperature $\left(11.4^{\circ} \mathrm{C}\right)$.

The area has been suffering from intense human land transformation (i.e., agriculture and mining; Moreno 1989), although these activities have been progressively abandoned since the mid-twentieth century (Vicente et al. 2009). During the last decades, reforestation activities have been carried out, favoring a recovery of the vegetal cover in the area by almost $50 \%$ (Vicente et al. 2009). Nowadays, the vegetation cover is formed mainly by Quercus ilex L. on calcareous sediments, and Pinus sylvestris L. and Pinus pinea Ait. on the silica sands in the gullies.

Sheet erosion rates have been quantified previously in the study area through monitoring campaigns using iron stakes and Gerlach sediment collectors between 2007 and 2011 (Lucia et al. 2011). Mean ablation rates obtained with annual monitoring range between 9 and $16 \mathrm{~mm} \mathrm{yr}^{-1}$ (Lucia et al. 2011). In addition, erosion rates at the medium term (up to 40 year) were also estimated based on the analysis of PAR which yielded values comprised between 6.2 and $8.8 \mathrm{~mm} \mathrm{yr}^{-1}$ (or 125.2$177.8 \mathrm{t} \mathrm{ha}^{-1} \mathrm{yr}^{-1}$; Bodoque et al. 2011).

\section{TLS measurements and sampling of exposed roots}

The field survey of this study was carried out in 2012 and included (i) an acquisition of micro-topographic data with a TLS (Leica Station 2) and (ii) the sampling of PER roots. Prior to micro-topography acquisition, we located, labelled, and marked existing PER roots in three different homogenous response units (HRU). Each of these units is localized on sandy outcrops characterized by moderate slopes $\left(<30^{\circ}\right)$, but has its own specificity (Fig. 2; Bodoque et al. 2011):

- HRU 1 is a poorly vegetated slope $\left(\sim 14^{\circ} \pm 5^{\circ}\right)$ characterized by a low density of exposed roots. Sheet erosion has been previously quantified in this HRU with iron stakes, micro plots equipped with Gerlach sediment collectors and dendrogeomorphic analyses of exposed PAR roots.

- HRU 2 is a steep $\left(\sim 26^{\circ} \pm 4^{\circ}\right)$ forested interfluve characterized by a high density of transversal roots and a dense litter of pine needles covering up to $60 \%$ of the surface of the sandy outcrop.

- HRU 3 is a bare interfluve with a general slope similar than HRU1 $\left(\sim 16^{\circ} \pm 5^{\circ}\right)$, where exposed sand lacks any vegetation cover or pine needles.

All selected HRUs containing PER roots were scanned using a TLS with a resolution of $1 \mathrm{~mm}$. At least three scans were performed from different angles to avoid shadows in topographic data (Buckley et al. 2008). Four mobile targets located around the exposed roots were scanned to allow overlap of point data taken from different bases (Buckley et al. 2008, Fig. 3). After

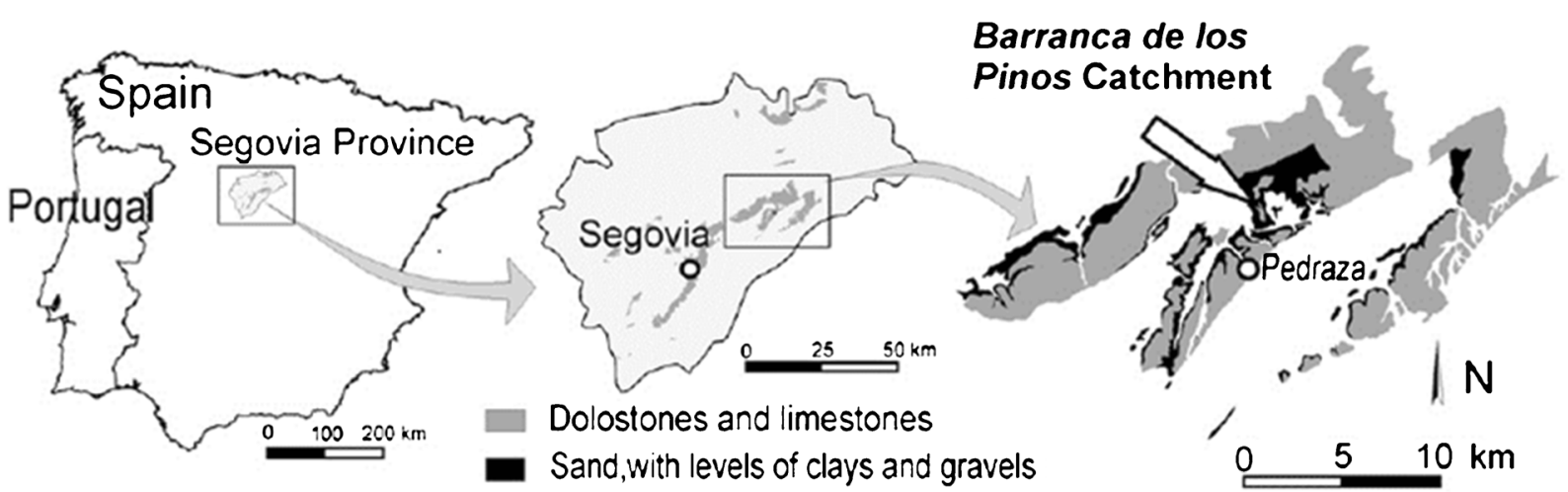

Fig. 1 The Barranca de los Pinos Catchment is located in the central part of Spain 

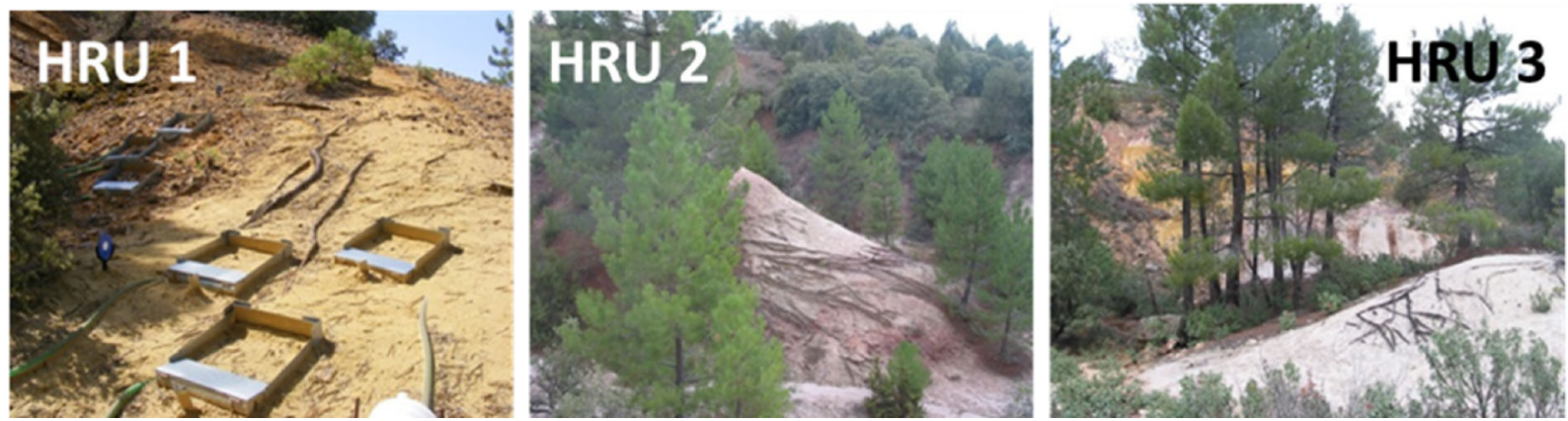

Fig. 2 Overview of the three Hydrological Response Units (HRU) analyzed in this study

TLS data acquisition, we sampled exposed roots with a handsaw. Additionally, we also sampled a small subset of buried roots at different soil depths (max. $10 \mathrm{~cm}$ ) to check for the observed bias related to root response under thin soil layer (Corona et al. 2011; Lopez-Sáez et al. 2011). Finally, each sample was permanently marked, stored and transported to the laboratory, where samples were dried at room temperature.

Assessing the time of roots exposure

Root sections were processed for macroscopic analyses according to the standard procedures described in Stoffel et al. (2013). Initially, cross-sections were polished with sandpaper (up to grit-size 400) to improve the visual recognition of tree rings. Then, all samples were observed under the binocular and root rings were counted and marked along 3 to 4 different radii. We also carried out a visual cross-dating procedure to assure the proper dating of growth-ring series.

The anatomical response of $P$. pinaster roots to exposure in this specific sandy badlands has been described in detail in previous studies (Bodoque et al. 2011, 2015). Two criteria have been retained to assess the first year of exposure, namely the (i) abrupt increase in the root-ring widths (change in ring width $>150 \%$; Stoffel and Corona 2014); and the (ii) abrupt increase in the percentage of latewood. In addition, in the case of root samples with diameters smaller $\sim 2 \mathrm{~cm}$ and poorly recognizable tree rings, micro sections were prepared following the procedures described in Rubiales et al. (2008). The $20-\mu \mathrm{m}$ thick transverse sections were cut using a Reichert sliding microtome. After staining with safranin (which makes lignin visible; Rubiales et al. 2008), samples were rinsed with water, alcohol and xylol, mounted on coated slides, coverslipped with Canada Balsam and dried at $60^{\circ}$ during $24 \mathrm{~h}$.

\section{Quantification of soil erosion}

The depth of the eroded layer has been derived with perpendicular profiles of the Digital Elevation Model (DEM) built from the TLS cloud of points. Initially, raw data was post-processed with a four-step procedure using the Cyclone software (Lucia et al. 2011) so as to (i) compute the bias resulting from the overlap procedure, (ii) extract the cloud of points corresponding to the area of interest, (iii) manually identify the points

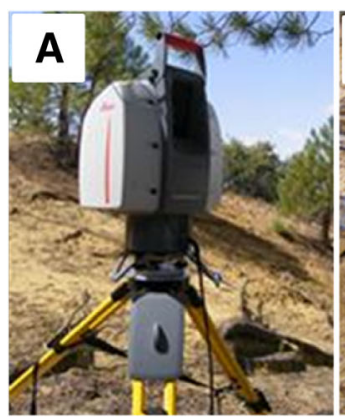

Fig. 3 a A Terrestrial Laser Scanner (TLS) was used to characterize microtopography. b Buried roots were used to determine the possible bias of exposure signals starting to form while the root

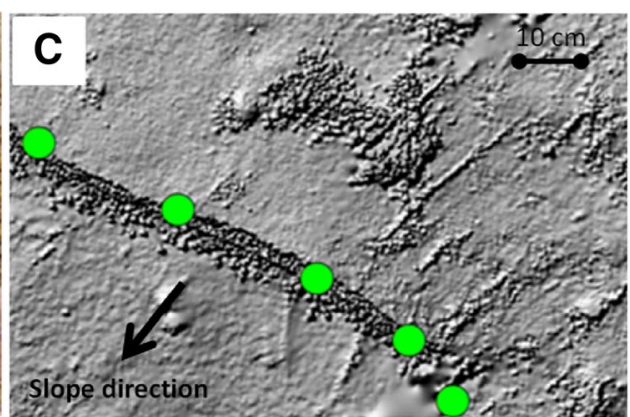

still has a thin edaphic cover. c Shadow representation of an exposed, perpendicular (PER) root in a digital elevation model 
corresponding to the border of each sampled root, and to (iv) export the cloud of points as a text file $(\mathrm{X}, \mathrm{Y}, \mathrm{Z})$ in a relative coordinate system. After the post-processing, text files were transferred to ArcGIS 10.1 and a DEM was derived with a precision of $3 \mathrm{~mm}$ using the Spatial Analysis Toolbox and the Inverse Distance Weighted (IDW) interpolation. Perpendicular sections, with an approximate length of $150 \mathrm{~cm}$, were then extracted from the DEM with the 3D Analysis Tool in ArcGIS (ESRI 2012) and exported to Excel files. For each section, we systematically measured the distance between the top of the root and a virtual planar surface tangential to the locally smoothed slope to remove localized, small-scale impacts of sedimentation and scour erosion (Fig. 4).

Erosion rate estimation and statistical analysis

Erosion rates (ER) have been computed according to the equation suggested by Corona et al. (2011):

$E_{R}=\frac{E_{S}-\left(G_{r 1}\right)+\left(\frac{B_{1}+B_{2}}{2}\right)+\varepsilon}{E_{y}}$

where $E_{y}(\mathrm{yr})$ is the number of rings formed since the year of exposure $(\mathrm{yr}) ; E_{S}(\mathrm{~mm})$ is the average thickness of the eroded soil layer extracted from DEM analysis; $G_{r 1}$ and $G_{r 2}(\mathrm{~mm})$ represent the secondary (subsequent) growth on the upper/lower side of the root after exposure; $B_{1}$ and $B_{2}(\mathrm{~mm})$ represent bark thickness on the upper/lower side of the root; and is the bias defined as the minimum thickness of soil below which roots start to modify their cell anatomy; bias has been defined following the analysis of a subset of buried root samples at the study site. The equation assumes that the radial growth pressure exerted by the root is higher than the mechanical impedance of the soil, i.e., its reaction to deformation by the root (Corona et al. 2011). This assumption is, therefore, in agreement with the results observed from soil cohesive tests carried out with a pocket penetrometer at the study site, which did not report any measure of unconfined compressive soil strength (Bodoque et al. 2011).

Finally, classical descriptive and non-parametric statistical procedures were applied at the $95 \%$ confidence interval level to characterize results. Significant differences between (i) existing short-term erosion rates obtained from direct measurement and (ii) reconstructed medium-term erosion rates based on the analysis of PAR roots were evaluated by means of a Friedman and Wilcoxon tests on paired values (Sprent and Smeeton 2001). The Friedman test was used to detect differences in average erosion rates (i) between HRU and (ii) quantified with direct measurement and PAR roots. Wilcoxon signed-rank test was used to detect significant differences between pairs of observations.

\section{Results}

Erosion rates from exposed PER roots

Table 1 shows the main variables of the 46 exposed PER roots analyzed: 26 samples in HRU 1; 6 samples in HRU 2 and 14 in HRU 3. Average root diameter was $33 \mathrm{~mm}$, ranging between 13 and $71 \mathrm{~mm}$. The year of initial root exposure ranges from 1969 to 2007, which allows definition of erosion rates at medium-term

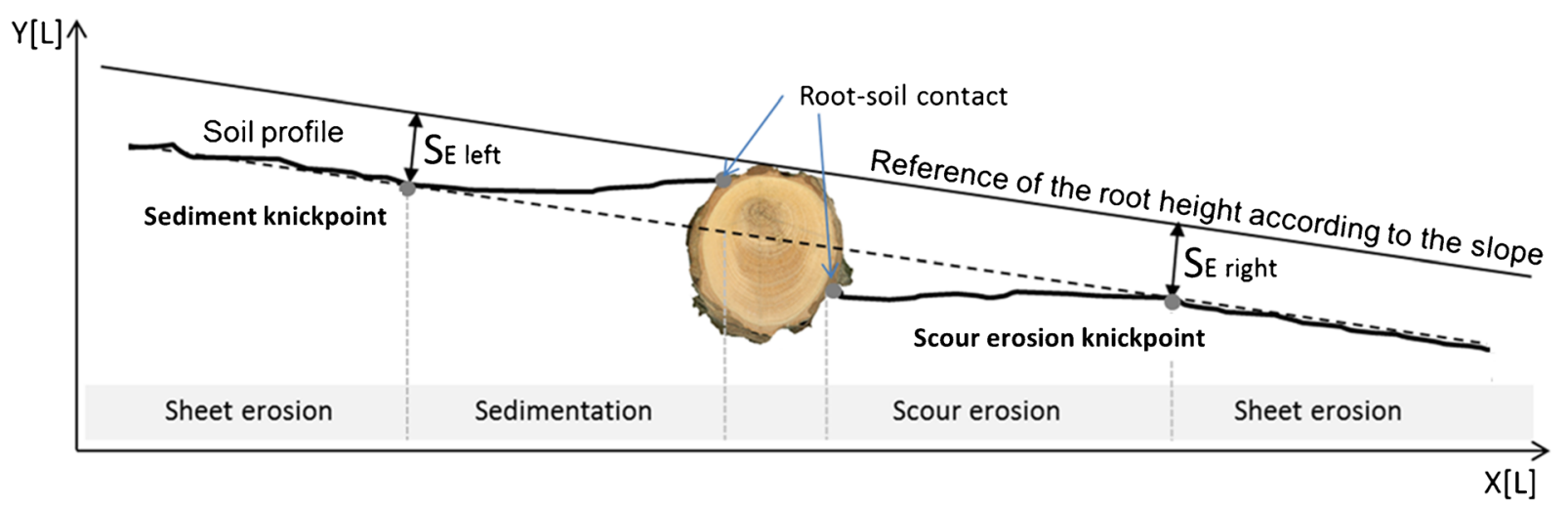

Fig. 4 Schematic view of root profile of an exposed perpendicular root. Soil erosion $\left(\mathrm{S}_{\mathrm{E}}\right)$ is measured at the knickpoint corresponding to existing sedimentation and scour erosion processes next to the root 
Table 1 Characterization of root sections sampled perpendicular to the slope and erosion rates as determined from wood anatomical changes

\begin{tabular}{|c|c|c|c|c|c|c|c|c|c|c|c|}
\hline \multirow{2}{*}{\multicolumn{6}{|c|}{$\begin{array}{l}\text { to the slope and erosion rates as determined from wood anatomical } \\
\text { changes }\end{array}$}} & \multirow[b]{2}{*}{ Site } & \multirow{2}{*}{$\begin{array}{l}\text { Slope } \\
\left({ }^{\circ}\right)\end{array}$} & \multirow{2}{*}{$\begin{array}{l}\text { Yr. of } \\
\text { expo. }\end{array}$} & \multirow[b]{2}{*}{$\begin{array}{l}\mathrm{E}_{\mathrm{s}} \\
(\mathrm{mm})\end{array}$} & \multirow[b]{2}{*}{$\begin{array}{l}\mathrm{E}_{\mathrm{s}}+ \\
(\mathrm{mm})\end{array}$} & \multirow[b]{2}{*}{$\begin{array}{l}\mathrm{E}_{\mathrm{R}} \\
(\mathrm{mm} / \mathrm{yr})\end{array}$} \\
\hline & & & & & & & & & & & \\
\hline Site & $\begin{array}{l}\text { Slope } \\
\left({ }^{\circ}\right)\end{array}$ & $\begin{array}{l}\text { Yr. of } \\
\text { expo. }\end{array}$ & $\begin{array}{l}E_{s} \\
(\mathrm{~mm})\end{array}$ & $\begin{array}{l}\mathrm{E}_{\mathrm{s}}+ \\
(\mathrm{mm})\end{array}$ & $\begin{array}{l}\mathrm{E}_{\mathrm{R}} \\
(\mathrm{mm} / \mathrm{yr})\end{array}$ & HRU 3 & 14.5 & 1989 & 61.2 & 90.0 & 3.9 \\
\hline \multirow[b]{2}{*}{ HRU 1} & \multirow[b]{2}{*}{18} & \multirow[b]{2}{*}{2002} & \multirow[b]{2}{*}{53.3} & \multirow[b]{2}{*}{82.1} & \multirow[b]{2}{*}{8.2} & HRU 3 & 3.4 & 1988 & 134.6 & 163.4 & 6.8 \\
\hline & & & & & & HRU 3 & 16.6 & \multirow{3}{*}{$\begin{array}{l}1981 \\
1990\end{array}$} & \multirow{3}{*}{$\begin{array}{l}28.1 \\
48.2\end{array}$} & \multirow{3}{*}{$\begin{array}{l}56.9 \\
77.0\end{array}$} & \multirow{3}{*}{$\begin{array}{l}1.8 \\
3.5\end{array}$} \\
\hline \multirow{2}{*}{$\begin{array}{l}\text { HRU } 1 \\
\text { HRU } 1\end{array}$} & 11.5 & 2000 & 16.4 & 45.2 & 3.8 & \multirow{2}{*}{ HRU 3} & \multirow{2}{*}{17.3} & & & & \\
\hline & 16 & 2001 & 51.6 & 80.4 & 7.3 & & & & & & \\
\hline
\end{tabular}

HRU 1

HRU 1

1997

24.9

53.7

3.6

HRU 1

1999

87.5

116.3

8.9

HRU $1 \quad 11.6$

1988

98.5

127.3

5.5

HRU 12

1989

143.3

172.1

7.2

HRU $1 \quad 6.7$

1997

104.0

132.8

5.8

HRU 19.9

1989

43.7

72.5

4.8

HRU 19.7

1995

53.3

82.1

3.6

HRU $1 \quad 5.7$

1993

57.6

86.4

5.1

HRU $1 \quad 18.4$

2004

60.7

89.5

4.7

HRU $1 \quad 18.4 \quad 2006$

23.7

52.5

6.6

HRU $1 \quad 18.4 \quad 2006$

40.9

69.7

11.6

HRU $1 \quad 23.4 \quad 2006$

54.7

83.5

13.9

HRU $1 \quad 19.6 \quad 2006$

56.9

85.7

14.3

57.1

85.9

14.3

HRU $1 \quad 19.9 \quad 2006$

64.1

92.9

15.5

HRU 12006

46.9

29.3

12.6

HRU $1 \quad 20.1 \quad 2006$

HRU $1 \quad 8.8 \quad 1999$

78.2

58.1

9.7

HRU 13.4

1997

HRU 111.9

2006

47.4

107.0

8.2

26.2

76.2

5.1

HRU $1 \quad 12.6$

2007

37.8

55.0

9.2

HRU $1 \quad 16.4$

1993

29.0

66.6

13.3

HRU $1 \quad 16.3$

1998

HRU $2 \quad 25.6$

1987

56.5

57.8

3.0

HRU 21.4

1992

51.6

85.3

6.1

80.4

3.2

HRU $2 \quad 22.7$

1991

HRU $2 \quad 25.6$

1987

60.8

89.6

4.5

67.9

96.7

4.6

HRU $2 \quad 32.8$

1993

HRU 27.1

1985

49.1

77.9

3.1

$106.1 \quad 134.9 \quad 7.1$

90.3

119.1

4.4

HRU $3 \quad 8.5 \quad 1994$

47.8

168.3

76.6

4.3

HRU $3 \quad 23.2$

1994

HRU 321

HRU $3 \quad 22.5$

1994

263.5

197.1

11.0

1990

269.4

292.3

16.2

HRU $3 \quad 16.3$

1969

251.4

298.2

13.6

HRU $3 \quad 18.8 \quad 1980$

232.2

280.2

6.5

HRU $3 \quad 16.3 \quad 1991$

HRU $3 \quad 17 \quad 1990$

HRU $3 \quad 15.4$

1990

105.6

261.0

8.2

48.2

134.4

6.4

104.

77.0

3.5

HRU $3 \quad 16.3$

2003
39.

$133.0-6.1$

$68.7 \quad 7.6$

Table 1 (continued)

HRU 1: gully slope without needles; HRU 2: gully slope with high density of exposed roots and needle litter; HRU 3: interfluve without needles. $\mathrm{E}_{\mathrm{s}}$ represents the total soil eroded measured as the distance between the top of the exposure root and the plane defined by the local slope. indicate the corrected bias related with the average soil depth roots start to respond (here assessed on $2.9 \mathrm{~cm}$ based on the field observation 6 samples). $E_{R}$ indicates the estimated erosion rates

(multi-decadal) timescales. In addition, we analyzed 10 buried roots to detect potential exposure signals occurring in roots which are still covered by a thin soil layer. Results indicate that buried roots start to react when the edaphic cover falls below $4 \mathrm{~cm}$ (Fig. 5). The bias involved in erosion rate reconstructions was defined as $2.9 \pm 0.9 \mathrm{~cm}$. Therefore, we consider this soil depth as the bias to be added to the height of the exposed root derived with DEM analysis.

The longitudinal extents of sedimentation and scour erosion processes at the vicinity of the roots are summarized in Fig. 6. On average, the influence of upslope sedimentation can be seen over a distance of 34, 27, and $29 \mathrm{~cm}$, whereas the influences micro-topography over a distance of 35, 17, and $25 \mathrm{~cm}$ for HRU 1, HRU 2 and HRU 3, respectively. Sheet erosion rates obtained with exposed PER roots at Barranca de los Pinos are 8.1 \pm $3.8 \mathrm{~mm} \mathrm{yr}^{-1}$ (HRU 1), $4.4 \pm 1.4 \mathrm{~mm} \mathrm{yr}^{-1}$ (HRU 2), and $7.3 \pm 4.1 \mathrm{~mm} \mathrm{yr}^{-1}$ (HRU 3). As a consequence, considering an average soil bulk density measured for the silica sands at the study site of $2.02 \mathrm{~g} \mathrm{~cm}^{-3}$ (Bodoque et al. 2011), erosion ranged between $163.5 \pm 66.6$ (HRU 1); $88.8 \pm 28.2$ (HRU 2), and 147.4 \pm 82.7 (HRU3) $\mathrm{t} \mathrm{ha}^{-1}$. The Wilcoxon sign-ranked test computed for each pair of HRU only indicates statistically significant differences between HRU 3 and HRU 2 ( $Z=-1.992$; $p$-val$\mathrm{ue}=0.046$ ), which is related to a reduction of sheet erosion by almost $50 \%$. The relationship between erosion rates $\left(\mathrm{mm} \mathrm{yr}^{-1}\right)$ and local slope $\left(^{\circ}\right)$ is presented in the scatter graph of Fig. 7, where linear regression indicates similar slope-erosion rate relationships for HRU $1\left(r^{2}=0.41\right)$ and HRU $3\left(r^{2}=0.25\right)$, whereas the 
Fig. 5 Overview of buried roots from Barranca de los Pinos analyzed in this study. Dark grey circles represent buried roots with exposure signals. The relative size of circles indicates root diameter (reduction $50 \%$ ), whereas the numbers indicate root depths

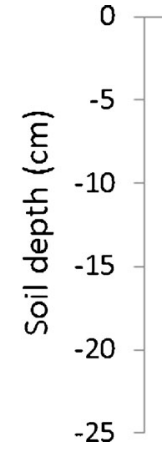

lower slope of the regression line for HRU $2 \mathrm{r}^{2}=0.41$ ) indicates a lower slope control over erosion rates.

Comparison of PER records with existing erosion records

Figure 8a compares erosion rates at the medium term (1969-2012) between this study (PER roots, growing perpendicular to the slope, but in three different HRU) with data obtained in the same area using exposed PAR roots (growing parallel to the slope). In addition, Fig. 8b shows the comparison of short-term erosion rates (2006-2012) between the obtained erosion rate based on roots and direct measurement (pins) in the same HRU.

In the medium term, the Wilcoxon test points to significant differences ( $p$-value $=0.025 ; Z=-2.234)$ between root-based PER (mean: $8.1 \mathrm{~mm} \mathrm{yr}^{-1}$ ) and

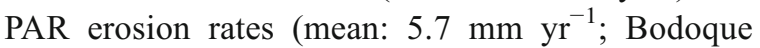
et al. 2011) in HRU1. At shorter timescales, however, erosion rates are not significantly different ( $p$-value $=0.593 ; Z=-0.535)$ between PER roots (HRU1: $12.7 \pm 2.1 \mathrm{~mm}$ yr-1; nobs=9) and values obtained by monitoring $\left(12.5 \pm 5.1 \mathrm{~mm} \mathrm{yr}^{-1} ; \mathrm{n}_{\mathrm{obs}}=\right.$ 5 years; Lucia et al. 2011).

\section{Discussion and conclusions}

In this study, we have tested the potential and accuracy of roots with positions perpendicular to the slope (PER) for the short- medium-term (i.e., multi-decadal) quantification of erosion rates in 46 exposed $P$. pinaster roots. Based on highly accurate micro-topography acquired with a TLS, we quantify the impact of upslope sedimentation and downslope scour erosion around exposed roots and derive eroded soil depths. TLS data was then coupled with a dendrogeomorphic analysis of exposed roots, based on techniques and assessments that were previously performed in the same badland, so as to reliable determine the first year of exposure in the root-ring series.

Macroscopic and microscopic observations indicate that $P$. pinaster reacts to exposure with eccentric growth and a significant increase of latewood tracheids, which is in agreement with previous observations made on other conifer roots (Gärtner et al. 2001; Rubiales et al. 2008; Bodoque et al. 2011; Corona et al. 2011). Reactions in $P$. pinaster start to occur at a time when the edaphic cover of the root falls below $2.9 \pm 0.8 \mathrm{~cm}$, and thus agree with observation from marly badlands in France where analysis was based on $P$. sylvestris and P. nigra (Corona et al. 2011). The early exposure reaction is interpreted as a response to increasing
Fig. 6 Dimension of the sediment and scour erosion influence close to the exposed roots for each analysed HRU

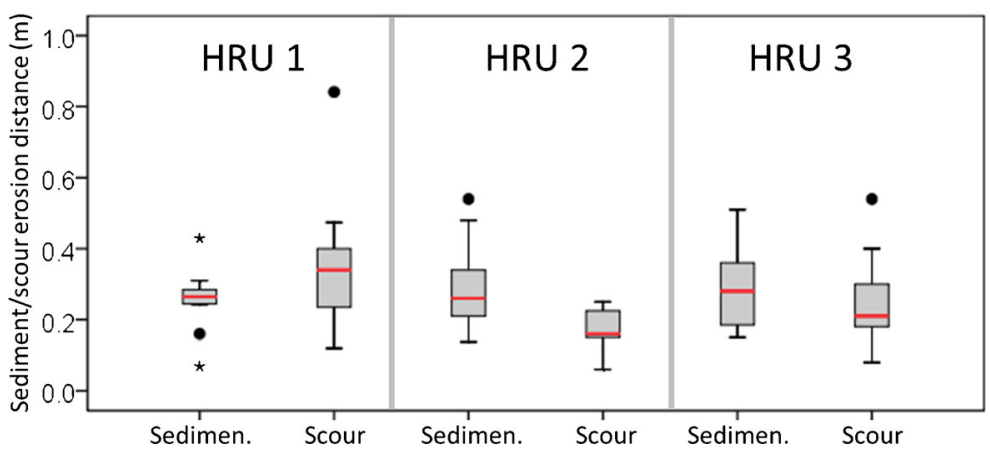


Fig. 7 Linear regression models taking into account erosion rates derived from anatomical changes in roots and local slopes derived from DEM analysis grouped by HRUs

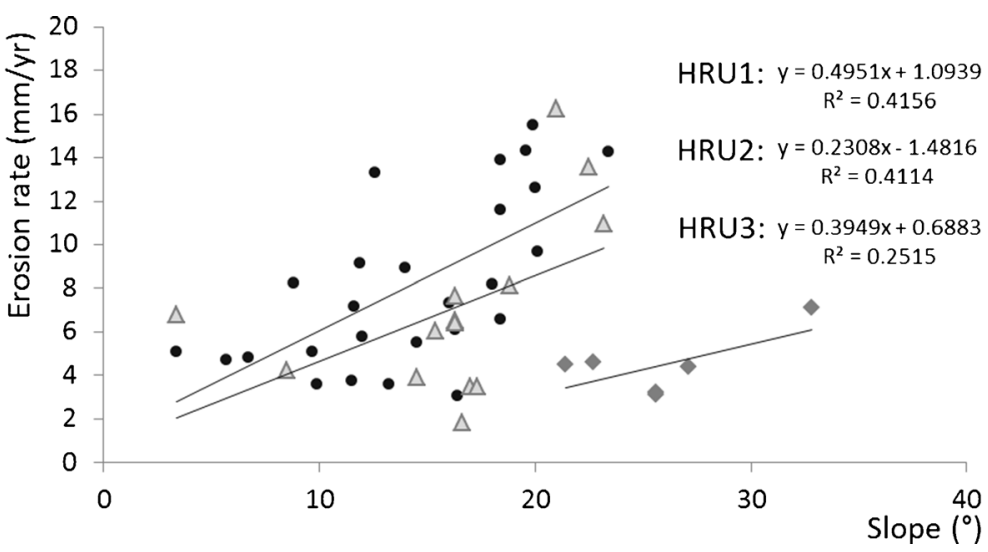

temperature variability and drought stress which will occur more easily in the upper detrital layer of loose sediment close to the soil surface (Antonova and Stasova 1993, 1997; Rubiales et al. 2008; Corona et al. 2011; Lopez-Sáez et al. 2011). This anatomical change can also be seen as an anticipated reaction of the root to reduce the risk of dysfunction of tracheids by cavitation due to ice crystal formation in sap (Zimmermann 1983) or by cell embolism related to water stress (Tyree and Sperry 1989), which can be considered as high in the highly porous and poorly cohesive sands present at the study site (Bodoque et al. 2011; Lucia et al. 2011). Our observations therefore confirm the hypothesis of Corona et al. (2011) and clearly suggest that past erosion rate estimates not taking account of this bias would have underestimated erosion activity. On the other hand, our study assumed ongoing secondary growth limited to the upper portion of the root following the hypothesis of Corona et al. (2011). This assumption is based the fact that low shear strengths have been observed in previous studies at our study site (Bodoque et al. 2011), suggesting that radial growth pressure exerted by the root is higher than soil impedance.

The erosion rates obtained in this study using PER roots suggest that the new approach yields values which are comparable to those obtained with direct measurements with erosion pins (Lucia et al. 2011), but significantly higher than the values reconstructed from exposed PAR roots (Bodoque et al. 2011). Our findings, therefore, confirm one of the conclusions of Corona et al. (2011), who did not find significant differences between erosion rates derived from iron stake monitoring and exposed roots in marly badlands in southeastern France. Results also underline that dendrogeomorphic erosion rates are of high quality and reliability and should thus be used more extensively in the analysis of erosion rates in areas where other data are not available (Stoffel et al. 2013). At the same time, however, our results indicate some disagreement in rates obtained when using exposed PER and PAR roots. We relate these differences to a possible underestimation of erosion rates to the fact that micro-topographic differences
Medium-term (1969 - 2012)

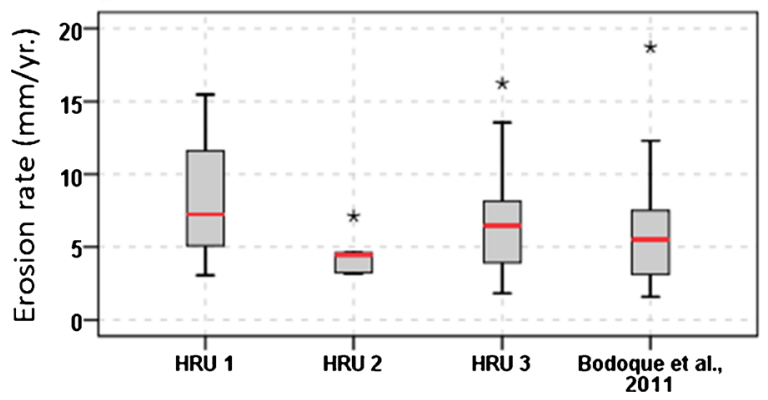

Fig. 8 Comparison of erosion rates derived from exposed perpendicular (PER) exposed roots (a) with erosion rates obtained using exposed roots growing parallel to the slope (Bodoque et al.

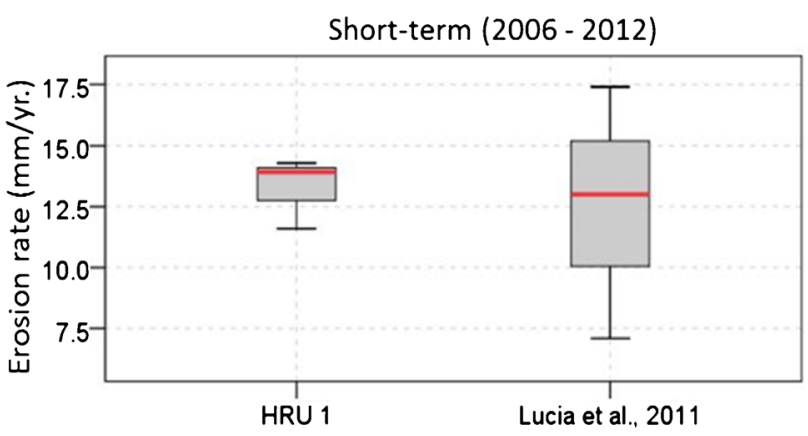

2011) as well as with (b) direct measurements obtained from erosion pins in HRU1 (Lucia et al. 2011) 
in soil morphology around the root have not been considered adequately in the past (Bodoque et al. 2011).

The main contribution of this paper is methodological, as its focus is on the inclusion of exposed PER roots and perpendicular soil profiles to soil erosion research. At the same time, this contribution has also allowed definition of reliable soil erosion depths by accurately defining the areas affected by upslope sedimentation (minimum distance $=27 \mathrm{~cm}$ ) and downslope scour (minimum distance $=17 \mathrm{~cm}$ ). Therefore, our findings suggest that exposed PER roots can be used as a reliable bioindicator of sedimentation and scour erosion processes on slopes. In this study, we have used a TLS to monitor sheet erosion processes as it is known for its high resolution and spatial accuracy (Lucia et al. 2011). However, and for replicative studies, laser profilmeters (Sole-Benet et al. 1997) or high-resolution photogrammetry could be acceptable lower-cost alternatives, especially for studies in remote areas where the use of TLS may not be possible.

Our study also shows differences in erosion rates in different HRU. Comparison of erosion rates between HRU suggests that pine needle cover can play an important role in the reduction of sheet erosion rates at the local scale. Therefore, we observed higher average erosion rates in HRUs void of pine needle litter (i.e., HRU1: $8.8 \mathrm{~mm} \mathrm{yr}^{-1}$ and HRU3: $7.3 \mathrm{~mm} \mathrm{yr}^{-1}$ ) than in the HRU covered with needles (HRU2: $4.4 \mathrm{~mm} \mathrm{yr}^{-1}$ ). Moreover, we observe an increase of erosion rates with increasing slope in HRU1 and HRU3 (see Fig. 7), although this dependence was less marked in HRU2, the site characterized by a high density of exposed roots and needles. Differences in HRUs are therefore related to the higher capacity of needles to absorb the energy of raindrops during precipitation events as well as by a greater capacity of areas with large numbers of exposed roots to reduce the tractive capacity of runoff (Park et al. 1983; Gyssels et al. 2005). This efficiency of needles against erosion has been demonstrated previously (Megahan and Molitor 1975; Cerdà and Doerr 2008). In the case of experimental plots, for instance, Pannkuk and Robichaud (2003) demonstrated that interill erosion was reduced by up to $80 \%$ in case that the plot area was $50 \%$ covered with needles. Gyssels et al. (2005) also argued that splash and interrill erosion are inversely proportional to the vegetation cover and thus highlighted the role of above biomass (i.e., leaves, needles) and mainly below biomass (density of roots) on erosion reduction. In additions, the authors also state that a shallow, but dense root network can protect against soil erosion, an observation which could also be confirmed by our study.

In conclusion, we demonstrated in this paper that (i) micro-topographic analyses are essential for the quantification of soil erosion thickness and thus call for a more systematic inclusion of such data in future studies; and that (ii) exposed PER roots should be used in the future for the estimation of sheet erosion, as they yielded results which are comparable to values obtained with erosion pins and/or exposed PAR roots in the same environment. Our findings therefore clearly improve the reproducibility and utility of dendrogeomorphic approaches by extending the typology of bioindicators that can be used to quantify erosion rates in ungauged basins.

Acknowledgments This study has been funded by the Spanish Research Projects CGL2010-21754-C02-01 of the Spanish Ministry of Science and Technology. The authors wish to thank Jose Francisco Martin Duque, Cristina Martín-Moreno and Luis Alberto de Frutos for their kind collaboration during fieldwork. This study is affectionately dedicated to Andy Godfrey who was the first to use dendrogeomorphology to analyze erosion in exposed tree roots of Central Spain.

\section{References}

Antonova GF, Stasova VV (1993) Effects of environmental factors on wood formation in Scots pine stems. Trees 7:214-219

Antonova GF, Stasova VV (1997) Effects of environmental factors on wood formation in larch (Larix sibirica Ldb.) stems. Trees $11: 462-468$

Ballesteros-Cánovas JA, Bodoque JM, Lucía A, Martín-Duque JF, Díez-Herrero A, Ruiz-Villanueva V, Rubiales JM, Génova M (2013) Dendrogeomorphology in badlands: methods, case studies and prospects. Catena 106:113-122

Bodoque JM, Díez-Herrero A, Martín-Duque JF, Rubiales JM, Godfrey A, Pedraza J, Carrasco RM, Sanz MA (2005) Sheet erosion rates determined by using dendrogeomorphological analysis of exposed tree roots: two examples from Central Spain. Catena 64:81-102

Bodoque JM, Lucía A, Ballesteros JA, Martín-Duque JF, Rubiales JM, Genova M (2011) Measuring medium-term sheet erosion in gullies from trees: a case study using dendrogeomorphological analysis of exposed pine roots in central Iberia. Geomorphology 134:417-425

Bodoque JM, Ballesteros JA, Lucía A, Díez-Herrero A, MartínDuque JF (2015) Source of error and uncertainty in sheet erosion rates estimated from dendrogeomorphology. Earth Surf Process Landf. doi:10.1002/esp.3701

Buckley SJ, Howell JA, Enge HD, Kurz TH (2008) Terrestrial laser scanning in geology: data acquisition, processing and accuracy considerations. J Geol Soc 165(3):625-638 
Carrara PE, Carroll TR (1979) The determination of erosion rates from exposed tree roots in the Piceance Basin, Colorado. Earth Surf Process Landf 4:307-317

Cerdà A, Doerr SH (2008) The effect of ash and needle cover on surface runoff and erosion in the immediate post-fire period. Catena 74:256-263

CNIG (2004) Atlas nacional de España. Sección II. Grupo 9. Climatología. Ministerio de Fomento, Madrid

Corona C, Saez JL, Rovera G, Stoffel M, Astrade L, Berger F (2011) High resolution, quantitative reconstruction of erosion rates based on anatomical changes in exposed roots at Draix, Alpes de Haute-Provence - critical review of existing approaches and independent quality control of results. Geomorphology 125:433-444

de Aguiar MI, Maia SMF, Xavier FAD, Mendonça ED, Araujo JA, de Oliveira TS (2010) Sediment, nutrient and water losses by water erosion under agroforestry systems in the semi-arid region in Northeastern Brazil. Agrofor Syst 79:277-289

ESRI (2012) 3D Analyst tutorial. Esri. http://help.arcgis.com/en/ arcgisdesktop/10.0/pdf/3d-analyst-tutorial.pdf

Gärtner H (2007) Tree roots - methodological review and new development in dating and quantifying erosive processes. Geomorphology 86:243-251

Gärtner H, Fritz H, Schweingruber FH, Dikau R (2001) Determination of erosion rates by analyzing structural changes in the growth pattern of exposed roots. Dendrochronologia 19:1-11

Giménez R, Marzolff I, Campo MA, Seeger M, Ries JB, Casalí J, Álvarez-Mozos J (2009) Accuracy of high-resolution photogrammetric measurements of gullies with contrasting morphology. Earth Surf Process Landf 34(14):1915-1926

Godfrey A, Everitt BL, Martín-Duque JF (2008) Episodic sediment delivery and landscape connectivity in the Mancos Shale badlands and Femont River system, Utah, USA. Geomorphology 102:242-251

Gómez-Gutiérrez A, Schnabel S, Berenguer-Sempere F, LavadoContador F, Rubio-Delgado J (2014) Using 3D photoreconstruction methods to estimate gully headcut erosion. Catena 120:91-101

Gyssels G, Poesen J, Bochet E, Li Y (2005) Impact of plant roots on the resistance of soils to erosion by water: a review. Prog Phys Geogr 29:189-217

Hooke RL (2000) On the history of humans as geomorphic agents. Geology 28:843-846

Lopez-Sáez J, Corona C, Stoffel M, Rovéra G, Astrade L, Berger F (2011) Mapping of erosion rates in marly badlands based on anatomical changes in exposed roots and LiDAR data. Earth Surf Process Landf 36:1162-1171

Lucia A, Laronne J, Martin-Duque JF (2011) Geodynamic processes on sandy slope gullies in central Spain field observations, methods and measurements in a singular system. Geodin Acta 24:61-79

Martínez-Casanovas JA, Ramos MC, García-Hernández D (2009) Effects of land-use changes in vegetation cover and sidewall erosion in a gully head of the Penedès region (northeast Spain). Earth Surf Process Landf 34(14):1927-1937

McAuliffe JR, Scuderi LA, McFadden LD (2006) Tree-ring record of hillslope erosion and valley floor dynamics: landscape responses to climate variation during the last $400 \mathrm{yr}$ in the Colorado Plateau, northeastern Arizona. Glob Planet Chang 50:184-201
Megahan WF, Molitor DC (1975) Erosional effects of wildfire and logging in Idaho. In: Watershed management symposium, Logan, UT, pp 423-444

Montgomery D (2007) Dirt: the erosion of civilizations. University of California Press, Berkeley

Moreno F (1989) Zonas kársticas en la vertiente N de la Sierra de Guadarrama. Dissertation, Universidad Complutense de Madrid

Morgan RPC (2009) Soil erosion and conservation. Wiley, New York

Nadal-Romero E, Martínez-Murillo JF, Venmaaercke M, Poesen J (2011) Scale dependency of sediment yield from badland areas in Mediterranean environments. Prog Phys Geogr 35(3):297-332

Nadal-Romero E, González-Hidalgo JC, Cortesi N et al (2015) Relationship of runoff, erosion and sediment yield to weather types in the Iberian Peninsula. Geomorphology 228:372-381

Pannkuk CD, Robichaud PR (2003) Effectiveness of needle cast at reducing erosion after forest fires. Water Resour Res 39(12): 1333-1344

Park SW, Mitchell JK, Bubenzer GD (1983) Rainfall characteristics and their relation to splash erosion. T ASAE 26:795-804

Pimentel D (2006) Soil erosion: a food and environmental threat. Environ Dev Sustain 8:119-137

Poesen J (2011) Challenges in gully erosion research. Landf Anal 17:5-9

Poesen J, Nachtergaele J, Verstraeten G, Valentin C (2003) Gully erosion and environmental change: importance and research needs. Catena 50:91-113

Quinton JN, Govers G, Van Oost K, Bardgett RD (2010) The impact of agricultural soil erosion on biogeochemical cycling. Nat Geosci 3:311-314

Rieke-Zapp DH, Nearing MA (2005) Digital close range photogrammetry for measurement of soil erosion. Photogramm Rec 20(109):69-87

Rubiales JM, Bodoque JM, Ballesteros JA, Díez A (2008) Response of Pinus sylvestris roots to sheet-erosion exposure: an anatomical approach. Nat Hazards Earth Syst Sci 8:223-231

Sole-Benet A, Calvo A, Cerdá A, Lazaro R, Pini R, Barbero J (1997) Influences of micro-relief patterns and plant cover on runoff related processses in badlands from Tabernas (SE Spain). Catena 31:23-38

Spalevic V, Curovic M, Borota D, Fustic B (2012) Soil erosion in the river basin Zelieznica, area of Bar, Montenegro. Agric For 54(08):1-4, 5-24

Sprent P, Smeeton NC (2001) Applied nonparamentric statistical methods. Chapman \& Hall/CRC, Boca Raton

Stoffel M, Corona C (2014) Dendroecological dating of geomorphic disturbance in trees. Tree Ring Res 70:3-20

Stoffel M, Corona C, Ballesteros Canovas JA, Bodoque JM (2013) Dating and quantification of erosion processes based on exposed roots. Earth Sci Rev 123:18-34

Sun L, Wang X, Hong J (2014) Response of anatomical structures in tree roots to an erosion event on the southeastern Tibetan Plateau. Geomorphology 204:617-624

Tyree MT, Sperry JA (1989) Characterization and propagation of acoustic emission signals in woody plants: towards an improved acoustic emission counter. Plant Cell Environ 12: 371-382

Verheijen FGA, Jones RJA, Rickson RJ, Smith CJ (2009) Tolerable versus actual soil erosion rates in Europe. Earth Sci Rev 94:23-38 
Vicente F, Sanz MA, Lucía A, Martín-Duque JF (2009) Evolución geomorfológica en tiempos históricos recientes de cárcavas del borde del piedemonte norte del Guadarrama. Estudio a partir de fuentes documentales. Bol R Soc Esp His Nat (Sección Geológica) 103(1-4):49-64
Walling DE, Webb BW (1986) Solutes in river systems. In: Trudgill ST (ed) Solute processes. Wiley-Interscience, Chichester, pp 251-327

Zimmermann MH (1983) Xylem structure and the ascent of sap. Springer Verlag, New-York 